\title{
Magalhães, I. ; Coracini, M. J. \& Grigoletto, M. (Orgs). Prá- ticas identitárias: língua e discurso. São Carlos: Claraluz, 2006. 282 págs.
}

\author{
Resenhado por Denise Tamaê B. Sato ${ }^{1}$ \\ (Universidade de Brasília)
}

Práticas Identitárias: língua e discurso é resultado de discussões do Grupo de Trabalho Práticas Identitárias na Linguística Aplicada, da Associação Nacional de Pós-Graduação e Pesquisa em Letras e Linguística/Anpoll, que investiga as práticas de linguagem em contextos sociais. O grupo objetiva compreender os mecanismos de inserção dos sujeitos nas práticas sociais e os efeitos dessas práticas na formação identitária de atores envolvidos.

As organizadoras desse livro: Maria Izabel Magalhães (UnB/ UFC), Marisa Grigoletto (USP) e Maria José Coracini (Unicamp) são pesquisadoras com significativas publicações na área de identidade e que contribuem para a percepção dos processos identitários decorrentes das transformações sociais geradas na atual fase, denominada por alguns teóricos de modernidade tardia.

A obra está dividida em quinze artigos, distribuídos em quatro eixos que se complementam: i) "Dimensões da alteridade", ii) "Identidade e políticas de representação", iii) "Novas tecnologias e subjetividades" e vi) "Identidades sociais e práticas discursivas em situações específicas". Essa estrutura permite ao/a leitor/a um olhar em profundidade acerca dos múltiplos aspectos dos estudos das identidades, bem como a avaliação de diferentes teorias utilizadas pelos/as autores/as.

A diversidade teórica, contudo, não chega a causar estranhamento, uma vez que os estudos compartilham de um princípio

1. Mestra e Doutoranda pelo Programa de Pós-Graduação em Linguística da UnB 
norteador comum que é o aspecto constitutivo da linguagem. Ao atentar que a linguagem ou discurso forma a sociedade e é por ela moldado, e que os processos identitários estão imbricados nas práticas sociais, entre elas a de linguagem, o olhar desses/as pesquisadores/as volta-se para as práticas, bem como para seus efeitos nos/as sujeitos/ as. Esse princípio comum está explicitado no seguinte trecho do livro:

A identidade é o elemento central que permite a articulação das diversas perspectivas de estudo numa área transdisciplinar. Parte de um processo social dinâmico, as identidades constituem-se nas relações sociais mediadas pela linguagem como parte das práticas sociais. (Pag. 5)

Para uma visualização da abordagem dessa obra passaremos a uma descrição dos eixos que a estruturam. No primeiro "Dimensões da alteridade" o tema é tratado em três textos. Os/as autores/as consideram a alteridade como formativa do ser, de seu processo identificatório. O termo pode ser assim descrito:

Como o sujeito só se presentifica na relação com o Outro, o próprio do sujeito psicanalítico é ser clivado e heterogêneo na sua estrutura: entre a ilusão egóica de identidade, ou seja, 'a ambição do ego de atingir uma igualdade com o ego ideal.' (Souza, 1994 in Grigoletto, 2006: 18)

A alteridade, então compreendida, remete a concepção de que as relações sociais constroem processos identitários. Nesses momentos, agindo em papéis e em relações com o outro, o indivíduo torna-se consciente, tanto de si mesmo como consciente dos outros. No segundo e terceiro texto desse eixo o livro trata da alteridade na construção docente, enfocando as relações pedagógicas e o poder inerente ao papel de professor/a.

Uma contribuição em relação ao primeiro eixo seria a utilização dos estudos identitários para a análise da mídia na construção coletiva de processos valorativos, que influenciam o indivíduo. A linguagem utilizada nos meios de comunicação veicula também conceitos que passam a ser representados como pertencente ao “eu” ideal. Vista 
assim, percebemos os mecanismos da linguagem definindo o poder e a voz dos atores, no caso professores/as, que buscam, constantemente, a competência do momento, em exclusão de um pensamento autônomo.

O segundo eixo "Identidades e políticas de representação" transfere o olhar do/a pesquisador/a para o outro. As identidades de pesquisadores/as também em constante processo de auto-construção e são passíveis de mutação, em virtude dos valores e das práticas. Assim, o olhar do outro "avaliador do conhecimento científico no Brasil"; do outro "informante ou colaborador/a" em pesquisas; do outro "estrangeiro enquanto apreciador/a da produção literária nacional publicada em antologias bilíngües” são abordados nesse eixo, com a contribuição de que os trabalhos alicerçam-se na prática etnográfica para a pesquisa de campo.

Ao explicitar que a comunidade científica pode estar do lado oposto, o do enxergado, os textos demonstram e complementam a idéia de alteridade, uma vez que o olhar do outro projetado sobre essa comunidade de prática provoca reações, criando uma imagem que em maior ou menor grau também constitui o ser e o fazer da comunidade científica.

No terceiro eixo: "Novas tecnologias e subjetividades, o livro aborda a questão da integração das chamadas Tecnologias da Informação e Comunicação - TIC a vida moderna. Os efeitos das TIC na identidade foram intensificados a partir da internet. Assim, os primeiros textos tratam da inclusão digital na preparação de cidadãos críticos; da construção de mundos virtuais, dos discursos produzidos por meio dessas tecnologias, e no quarto texto há um aprofundamento nos mecanismos de atuação dessas tecnologias, principalmente, na forma de compreensão da relação espaço-tempo e do modo como a interação virtual se realiza.

Os trabalhos desse terceiro eixo promovem o debate acerca da formação identitária no mundo virtual. Contudo, adentram, igualmente, na materialização e nos efeitos da produção virtual no mundo real. As barreiras de poder do mundo real seriam relativamente superadas pela posse da tecnologia, que tornaria o indivíduo capaz de mobilizar outros sujeitos. A ação, que parte de um ponto material, 
ganha dimensão no mundo virtual, produz seus efeitos e volta-se para o real novamente. O real seria o nascedouro da ação e também o ponto de recepção, enquanto que a ação mediada pela tecnologia torna-se mais ampla.

No último eixo "Identidades sociais e práticas discursivas em situações específicas” a obra ilustrará o modus operandi dos discursos. Os contextos são diversos e as identidades formadas nas práticas recebem seus reflexos. Assim, vemos as interações em narrativas de sala de aula, as falas de uma conversão religiosa, o diálogo em uma central de atendimento telefônico e, por fim, as mensagens de correio eletrônico dentro de uma empresa, demonstrando que papéis e identidades são construções contínuas.

Voltando ao aspecto inicial da obra, compreender a prática social como formadora de identidades, tendo como foco a prática de linguagem como mediadora da ação social humana, o livro confere alguns insights sem, contudo, aproximar-se da explanação de mecanismos macros. A atenção em textos fragmentados de práticas ou a atenção demasiadamente fechada ao lócus da prática não permitiu que o olhar do/a investigador/a emergisse para as estruturas sociais que garantem a manutenção de determinadas construções identitárias. Estruturas que constrangem a prática, facilitando determinadas posições e não outras, ou a assimilação dos indivíduos de aspectos identitários emancipatórios. Nesse sentido, a pesquisa aqui apresentada tem seu papel no despertamento crítico que produz, e por isso, nas possibilidades de formulação de novas configurações para as práticas sociais, principalmente, as da pesquisa científica.

Recebido em: junho de 2009 Aprovado em: dezembro de 2009 denisetamae@gmail.com 